\title{
Leucocytoclastic vasculitis
}

\author{
Anirban Bhattacharyya, Kalpana Yeddula, Nwabundo Nwankwo, Mourad H Senussi
}

Department of Internal Medicine, Saint Joseph Hospital, Chicago, Illinois, USA

\section{Correspondence to}

Dr Mourad H Senussi, mouradsenussi@gmail.com
To cite: Bhattacharyya $A$, Yeddula K, Nwankwo N, et al. BMJ Case Rep Published online: [please include Day Month Year] doi:10.1136/bcr-2013009408

\section{DESCRIPTION}

A 75-year-old man, with no relevant medical history, was being evaluated for a 3-day history of gingival bleeding. $\mathrm{He}$ also reported generalised fatigue for 2 weeks prior to admission. He denied fever, chills, dyspnoea or weight loss. On examination, pallor of the conjunctival membranes and multiple bilateral lower extremity petechiae were noted with no lymphadenopathy or hepatosplenomegaly. Complete blood count revealed white blood cell $4.2 \times 10^{3} / \mathrm{mm}^{3}$, haemoglobin $6.5 \mathrm{~g} / \mathrm{dl}$ and platelets $6 \times 10^{3} / \mathrm{mm}^{3}$. International normalised ratio was 1.3. A bone marrow biopsy with cytogenetics and flow confirmed the presence of hypercellular marrow with infiltrating blasts consistent with M2 type acute myeloid leukaemia. Two days after completion of induction chemotherapy with idarubicin and cytarabine the patient developed a non-pruritic palpable maculopapular eruption starting over the right thigh which spread to all four extremities (figure 1).

Skin biopsy revealed perivascular and neutrophilic infiltrates and extravasated blood cells in the upper dermis consistent with leukocytoclastic vasculitis (figure 2). The rash continued to spread and coalesce over the course of 1 week (figure 3 ) and resolved spontaneously by day 10 .

Although malignancy represents a relatively rare cause of cutaneous vasculitis, there is a strong association with lymphoproliferative and myeloproliferative diseases. Leukocytoclastic vasculitis is the most common form of cutaneous vasculitis associated with lymphoproliferative disorders. The skin lesions may precede, occur concomitantly with or follow the onset malignancy. ${ }^{1}$

Cutaneous leukocytoclastic vasculitis is a clinicopathological entity characterised by palpable purpura commonly occurring in the lower extremities. Treatment is usually aimed at the underlying cause. $^{2}$

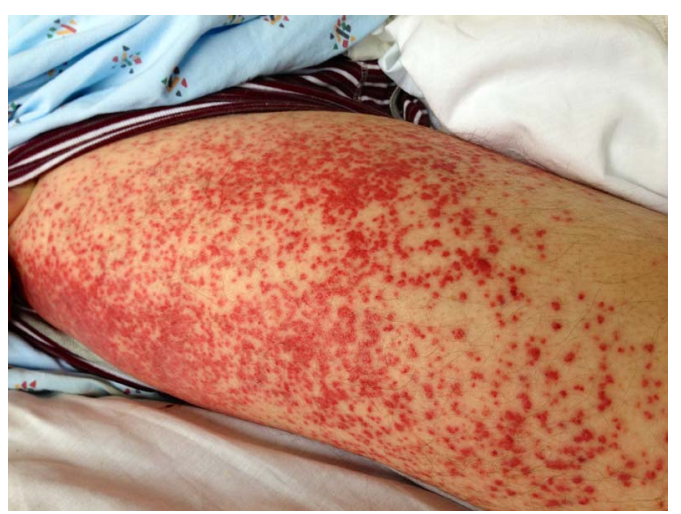

Figure 1 Non-pruritic palpable maculopapular eruption.

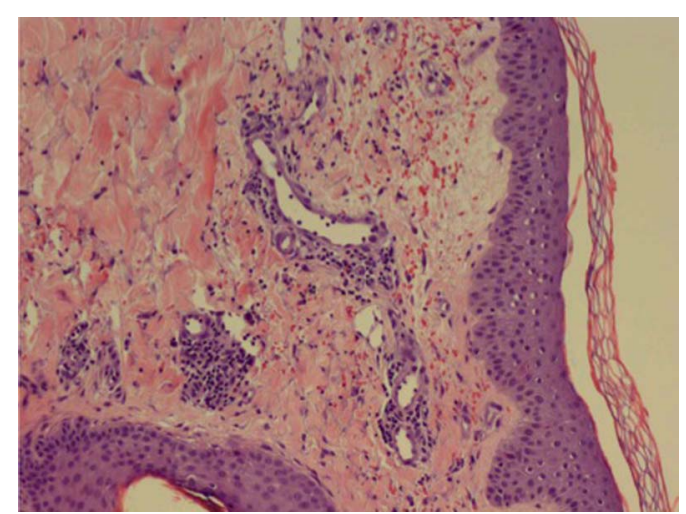

Figure 2 Skin biopsy revealing perivascular and neutrophilic infiltrates and extravasated blood cells in the upper dermis consistent with leukocytoclastic vasculitis.

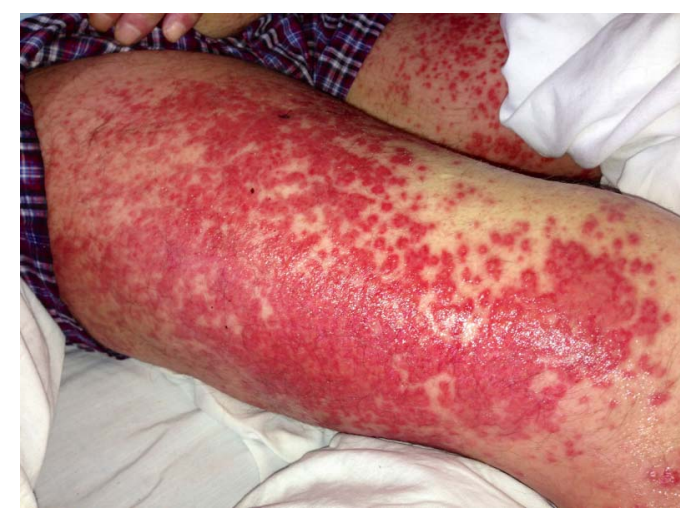

Figure 3 Spreading and coalescing of maculopapular rash day 7 .

\section{Learning points}

- The vasculitides are a heterogeneous group of clinical disorders that may be idiopathic or associated with connective tissue disorders, bacterial and viral infections, medications, sepsis or neoplasms particularly haematological malignancies. $^{3}$

- Cutaneous leucocytoclastic vasculitis is a clinicopathological entity characterised clinically by palpable purpura most commonly occurring in the lower extremities, and confirmed by skin biopsy. ${ }^{1}$

- Leukocytoclastic vasculitis should alert the physician to possible diagnoses such as haematological malignancies.

- Treatment is usually aimed at the underlying cause, stopping the offending agent or use of prednisone or immunosuppressive agents such as cyclophosphamide, azathioprine and methotrexate. 


\section{Competing interests None.}

Patient consent Obtained.

Provenance and peer review Not commissioned; externally peer reviewed.

\section{REFERENCES}

1 Wooten MD, Jasin HE. Vasculitis and lymphoproliferative diseases. Semin Arthritis Rheum 1996;26:564-74.
2 Koutkia P, Mylonakis E, Rounds S, et al. Leucocytoclastic vasculitis: an update for the clinician. Scand J Rheumatol 2001;30:315-22.

3 Bourantas K, Malamou-Mitsi VD, Christou L, et al. Cutaneous vasculitis as the initial manifestation in acute myelomonocytic leukemia. Ann Intern Med 1994;121:942-4.

Copyright 2013 BMJ Publishing Group. All rights reserved. For permission to reuse any of this content visit http://group.bmj.com/group/rights-licensing/permissions.

BMJ Case Report Fellows may re-use this article for personal use and teaching without any further permission.

Become a Fellow of BMJ Case Reports today and you can:

- Submit as many cases as you like

- Enjoy fast sympathetic peer review and rapid publication of accepted articles

- Access all the published articles

- Re-use any of the published material for personal use and teaching without further permission

For information on Institutional Fellowships contact consortiasales@bmjgroup.com

Visit casereports.bmj.com for more articles like this and to become a Fellow 